\title{
Analisis Pengaruh Unsur Lingkungan Pengendalian (Control Environment) terhadap Keandalan Laporan Keuangan.
} (Studi Kasus pada Kementerian/Lembaga di Indonesia)

\author{
AGUNG BUDIARTONO \\ Universitas Diponegoro Semarang \\ Email: agung.budiartono@gmail.com
}

\section{Diterima 3 Desember 2019; disetujui 17 Desember 2019}

\begin{abstract}
This study aimed to examine the effect of the Control Environment to reliability of Ministry/Agency financial statements in Indonesia. The elements of Control environment are tested, there are integrity and ethic value, commitment to competence, Supporting leadership, Organizational Structure, Authority and Responsibility, Human Resources Policy, The effectiveness of Government internal Audit, and Relationship with other agency. The population of this study are all the ministry/agency in Indonesia, and each of Ministry/ agency is represented by a person who presenting financial statements as respondents. The data in this study use primary data obtained from questionnaires distributed directly to the respondent. The Data collected are 59 questionnaires, from 86 questionnaires were distributed. The Data was analyzed using SmartPLS 3.0. The result shows that from 8 variables of Control Environment, only 2 that have effect to reliability of financial statements, there are The effectiveness of Government Internal Audit and Relationship with other agency. While others variables such as integrity and ethic value, commitment to competence, Supporting leadership, Organizational Structure, Authority and Responsibility, Human Resources Policy doesn't have effect to reliability of ministry/agency financial statements.
\end{abstract}

Keywords: Control Environment, Government Internal Control System, integrity and ethic value, commitment to competence, Supporting leadership, Organizational Structure, Authority and Responsibility, Human Resources Policy

\section{PENDAHULUAN}

Latar Belakang. Dalamrangka mewujudkan transparansi dan akuntabilitas pengelolaan keuangan negara, pemerintah menyusun dan menyajikan laporan pertanggungjawaban atas pelaksanaan APBN. Laporan pertanggungjawaban tersebut tertuang dalam bentuk Laporan Keuangan Pemerintah Pusat (LKPP). Sesuai dengan amanat Undang-undang Nomor 1 Tahun 2004 sebelum disampaikan kepada DPR, LKPP perlu disampaikan terlebih dahulu kepada Badan Pemeriksa Keuangan (BPK) untuk diaudit.

Hasil audit BPK atas LKPP tahun 2013 menyatakan opini "Wajar Dengan Pengecualian
(WDP). Opini WDP ini merupakan opini yang kelima kalinya sejak LKPP Tahun 2009. Sebelumnya atas LKPP tahun 2004 sampai dengan LKPP tahun 2008, BPK memberikan opini audit "Tidak Menyatakan Pendapat" atau "Disclaimer Opinion". Pemerintah terus melakukan upayaupaya perbaikan dalam meningkatkan transparansi dan akuntabilitas pengelolaan keuangan negara melalui peningkatan kualitas LKPP agar mendapatkan opini "Wajar Tanpa Pengecualian (WTP)."

Hingga tahun 2013 masih banyak K/L yang belum dapat meraih Opini WTP atas laporan keuangannya, hal inilah yang menyebabkan sulitnya mewujudkan opini WTP untuk LKPP, mengingat 
Laporan Keuangan K/L menjadi salah satu komponen utama dalam penyusunan LKPP, selain komponen utama lainnya yaitu LKBUN. salah satu faktor penyebab menurunnya kualitas laporan keuangan adalah terkait dengan lemahnya sistem pengendalian intern (SPI), ini tersirat dalam siaran pers BPK (2014) saat penyerahan LHP atas laporan keuangan tahun 2013 yang menyatakan masih banyak permasalahan dalam $\mathrm{K} / \mathrm{L}$ yang terkait dengan kelemahan SPI sehingga sangat mempengaruhi opini auditor.

Sistem Pengendalian Intern Pemerintah (SPIP) merupakan proses yang integral pada tindakan dan kegiatan yang dilakukan secara terus menerus oleh pimpinan dan seluruh pegawai untuk memberikan keyakinan memadai atas tercapainya tujuan organisasi melalui kegiatan yang efektif dan efisien, keandalan pelaporan keuangan, pengamanan aset negara, dan ketaatan terhadap peraturan perundang-undangan yang berlaku. SPIP dibentuk oleh pemerintah melalui PP No. 60 tahun 2008. Peraturan pemerintah ini merupakan amanah Pasal 58 Undang-undang No. 1 Tahun 2004 tentang Perbendaharaan Negara, bahwa dalam rangka meningkatkan kinerja, transparansi, dan akuntabilitas pengelolaan keuangan negara, Presiden selaku Kepala Pemerintahan mengatur dan menyelenggarakan sistem pengendalian intern di lingkungan pemerintahan secara menyeluruh melalui dengan penetapan sebuah Peraturan Pemerintah.

Keandalan laporan keuangan adalah salah satu dari tujuan dibentuknya SPIP, keandalan informasi dalam laporan keuangan merupakan wujud dari pertanggungjawaban pengelolaan keuangan publik. D'Aquila (1998) berpendapat Tujuan utama dari Pengendalian Internal adalah untuk mendapatkan keyakinan yang memadai tentang pelaporan keuangan. Keandalan laporan keuangan K/L menjadi unsur yang paling penting dalam rangka menciptakan opini WTP atas LKPP.

Sistem pengendalian intern pemerintah (SPIP) memiliki lima buah unsur yaitu : lingkungan pengendalian, penilaian resiko, kegiatan pengendalian, informasi dan komunikasi, serta pemantauan. Secara struktur Unsur Lingkungan pengendalian diletakkan pada bagian yang paling bawah sebagai landasan "suatu rumah" sistem pengendalian intern pemerintah. Dengan demikian, unsur lingkungan pengendalian merupakan fondasi dari unsur-unsur pengendalian intern lainnya sehingga unsur lingkungan pengendalian memiliki pengaruh yang sangat signifikan terhadap efektifitas pelaksanaan sistem pengendalian intern pemerintah (BPKP, 2009). Pendapat lain dari Messier et al (2006) menjelaskan juga bahwa lingkungan pengendalian merupakan dasar untuk semua komponen pengendalian internal yang efektif, menyediakan disiplin dan struktur. Dari definisi tersebut diatas dapat disimpulkan bahwa lingkungan pengendalian memegang peranan penting dalam efektifitas pelaksanaan SPIP di suatu entitas.

\section{TINJAUAN TEORETIS}

Teori Keagenan (Agency Theory). Teori keagenan merupakan basis teori yang mendasari praktik bisnis perusahaan yang dipakai selama ini. Teori tersebut berakar dari sinergi teori ekonomi, teori keputusan, sosiologi, dan teori organisasi. Prinsip utama teoriini menyatakan adanya hubungan kerja antara pihak yang memberi wewenang yaitu investor dengan pihak yang menerima wewenang (agensi) yaitu manajer.

Dalam teori keagenan paling tidak terdapat dua pihak yang dapat diidentifikasi yaitu pihak yang mempercayakan sumber daya yang dimilikinya kepada pihak lain, yang disebut principal. Sedangkan pihak yang kedua dinamakan agen yang diperankan oleh direksi dan manajemen perusahaan. Hubungan keagenan ada ketika principal mempekerjakan agen, untuk selanjutnya principal mendelegasikan tanggung jawab kepada agen (Baiman, 1990).

Sejalan dengan teori keagenan (Agency Theory), pada prinsipnya pemerintah merupakan orang suruhan atau agen dari rakyat. Rakyat dalam hal ini diwakili oleh DPR, Pemerintah diberi kekuasaan untuk memungut uang dari rakyat berdasarkan Undang-undang. Setiap tahunnya anggaran pendapatan dan belanja negara dituangkan dalam undang-undang APBN. Pemerintah yang memungut, pemerintah yang mengelola, maka pemerintah juga berkewajiban untuk mencatat (mengakuntasikan) dan melaporkannya kepada rakyat melalui DPR. Dalam rangka meyakini bahwa laporan dimaksud telah menyajikan kondisi yang 
sesungguhnya serta pemerintah telah menaati ketentuan peraturan perundang-undangan, maka laporan keuangan tersebut wajib diperiksa oleh pemeriksa yang independen. Berdasarkan UUD 45 yang berwenang untuk melakukan pemeriksaan atas laporan keuangan pemerintah adalah BPK RI.

Laporan Keuangan Sektor Publik. Laporan keuangan organisasi sektor publik merupakan komponen penting untuk menciptakan akuntabilitas sektor publik. Tuntutan yang besar terhadap akuntabilitas publik berimplikasi pada manajemen publik untuk memberikan informasi kepada publik, salah satunya adalah informasi akuntansi yang berupa laporan keungan (Mardiasmo, 2004).

Secara spesifik, tujuan pelaporan keuangan pemerintah atau sektor publik adalah untuk menyajikan informasi yang berguna untuk pengambilan keputusan dan untuk menunjukkan akuntabilitas entitas pelaporan atas sumber daya yang dipercayakan kepadanya, dengan :

a) Menyediakan informasi mengenai posisi sumber daya ekonomi, kewajiban, dan ekuitas dana pemerintah

b) Menyediakan informasi mengenai perubahan posisi sumber daya ekonomi, kewajiban, dan ekuitas dana pemerintah

c) Menyediakan informasi mengenai sumber, alokasi, dan penggunaan sumber daya ekonomi

d) Menyediakan informasi mengenai ketaatan realisasi terhadap anggarannya

e) Menyediakan informasi mengenai cara entitas pelaporan mendanai aktivitasnya dan memenuhi kebutuhan kas nya

f) Menyediakan informasi mengenai potensi pemerintah untuk membiayai penyelenggaraan kegiatan pemerintahan

g) Menyediakan informasi yang berguna untuk mengevaluasi kemampuan entitas pelaporan dalam mendanai aktivitasnya. (Kawedar et al, 2008)

Keandalan Laporan Keuangan. Keandalan laporan keuangan adalah salah satu tujuan dibentuknya SPIP, yang tertuang dalam PP No. 60 tahun 2008 maupun COSO'S Internal ControlIntegrated Framework adalah untuk memberikan keyakinan memadai atas tercapainya tujuan organisasi melalui keandalan laporan keuangan. Menurut Standar Akuntansi Pemerintahan PP 71 tahun 2010 Andal dalam laporan keuangan berarti informasi dalam laporan keuangan bebas dari pengertian yang menyesatkan dan kesalahan material, menyajikan setiap fakta secara jujur, serta dapat diverifikasi. Informasi yang andal memenuhi karakteristik :

a. Penyajian Jujur. Informasi menggambarkan dengan jujur transaksi serta peristiwa lainnya yang seharusnya disajikan atau yang secara wajar dapat diharapkan untuk disajikan.

b. Dapat Diverifikasi (Verifiability). Informasi yang disajikan dalam laporan keuangan dapat diuji, dan apabila pengujiannya dilakukan lebih dari sekali oleh pihak yang berbeda, hasilnya tetap menunjukkan simpulan yang tidak berbeda jauh.

c. Netralitas. Informasi diarahkan pada kebutuhan umum dan tidak berpihak pada kebutuhan pihak tertentu.

Sistem Pengendalian Intern. Definisi tentang Sistem pengendalian intern telah dipaparkan oleh beberapa ahli ekonomi akuntansi. Berikut ini definisi pengendalian intern menurut Mulyadi (2002), sistem pengendalian intern adalah suatu sistem yang meliputi struktur organisasi, metode dan ukuranukuran yang dikoordinasikan untuk menjaga kekayaan organisasi, mengecek ketelitian dan keandalan data akuntansi, mendorong efisiensi dan mendorong dipatuhinya kebijakan manajemen.

Menurut Committee of Sponsoring Organization of the Treadway Commission (COSO) pada tahun 1992 mengeluarkan definisi tentang pengendalian internal. Definisi COSO tentang pengendalian intern sebagai berikut :

"Internal control is process, affected by entilty's board of directors, management and other personnel, designed to provide reasonable assurance regarding the achievement of objectives in the following categories :

1. Effectiveness and efficiency of operations

2. Realibilty of Financial Reporting

3. Compliance with appli cable laws and regulation

COSO memandang pengendalian internal merupakan rangkaian tindakan yang mencakup keseluruhan proses dalam organisasi. Pengendalian internal berada dalam proses manajemen dasar, yaitu perencanaan, pelaksanaan, dan pemantauan. Pengendalian bukanlah sesuatu yang ditambahkan 
dalam proses manajemen tersebut, akan tetapi merupakan bagian integral dalam proses tersebut.

Kerangka Pemikiran Teoritis. Kerangka pemikiran teoritis yang dikembangkan dalam penelitian ini yang ditujukan untuk menganalisis pengaruh 8 (delapan) sub unsur lingkungan pengendalian yaitu : (1) Penegakan Integritas dan Etika; (2) Komitmen terhadap kompetensi; (3) Kepemimpinan Yang Kondusif; (4) Struktur Organisasi; (5) Wewenang dan tanggung jawab; (6) Kebijakan sumber daya manusia yang sehat; (7) Peran Aparat Pengawas Intern yang Efektif; (8) Hubungan dengan Instansi lain. Kedelapan sub unsur tersebut dijadikan variabel independen, dan akan diuji pengaruhnya terhadap keandalan laporan keuangan K/L. Gambaran mengenai pengaruh delapan variabel tersebut disajikan dalam gambar 1.

Hipotesis Penelitian. Hipotesis dirumuskan sebagai berikut :

H1 : Integritas dan Etika berpengaruh positif terhadap Keandalan Laporan Keuangan.

H2 :Komitmen terhadap kompetensi berpengaruh positif terhadap keandalan laporan keuangan
H3 : Kepemimpinan yang kondusif berpengaruh positif terhadap keandalan laporan keuangan

H4 : Kebijakan sumber daya manusia berpengaruh positif terhadap keandalan laporan keuangan

H5 : Struktur Organisasi yang sesuai berpengaruh positif terhadap Keandalan laporan keuangan

H6 :Pendelegasian wewenang dan tanggung jawab yang tepat berpengaruh positif terhadap keandalan laporan keuangan.

H7 : Efektivitas peran APIP berpengaruh positif terhadap keandalan laporan keuangan

H8 : Hubungan kerja yang baik dengan instansi lain berpengaruh positif terhadap keandalan laporan keuangan.

\section{METODE PENELITIAN}

Populasi dan Sampel. Dalam penelitian ini populasi yang digunakan adalah Petugas Penyusun Laporan Keuangan di lingkungan K/L yaitu sebanyak $87 \mathrm{~K} / \mathrm{L}$. Dalam penelitian ini peneliti menggunakan metode sensus dalam pengumpulan datanya, sedangkan sampel yang digunakan dalam

\section{Gambar 1}

\section{Kerangka Pemikiran}

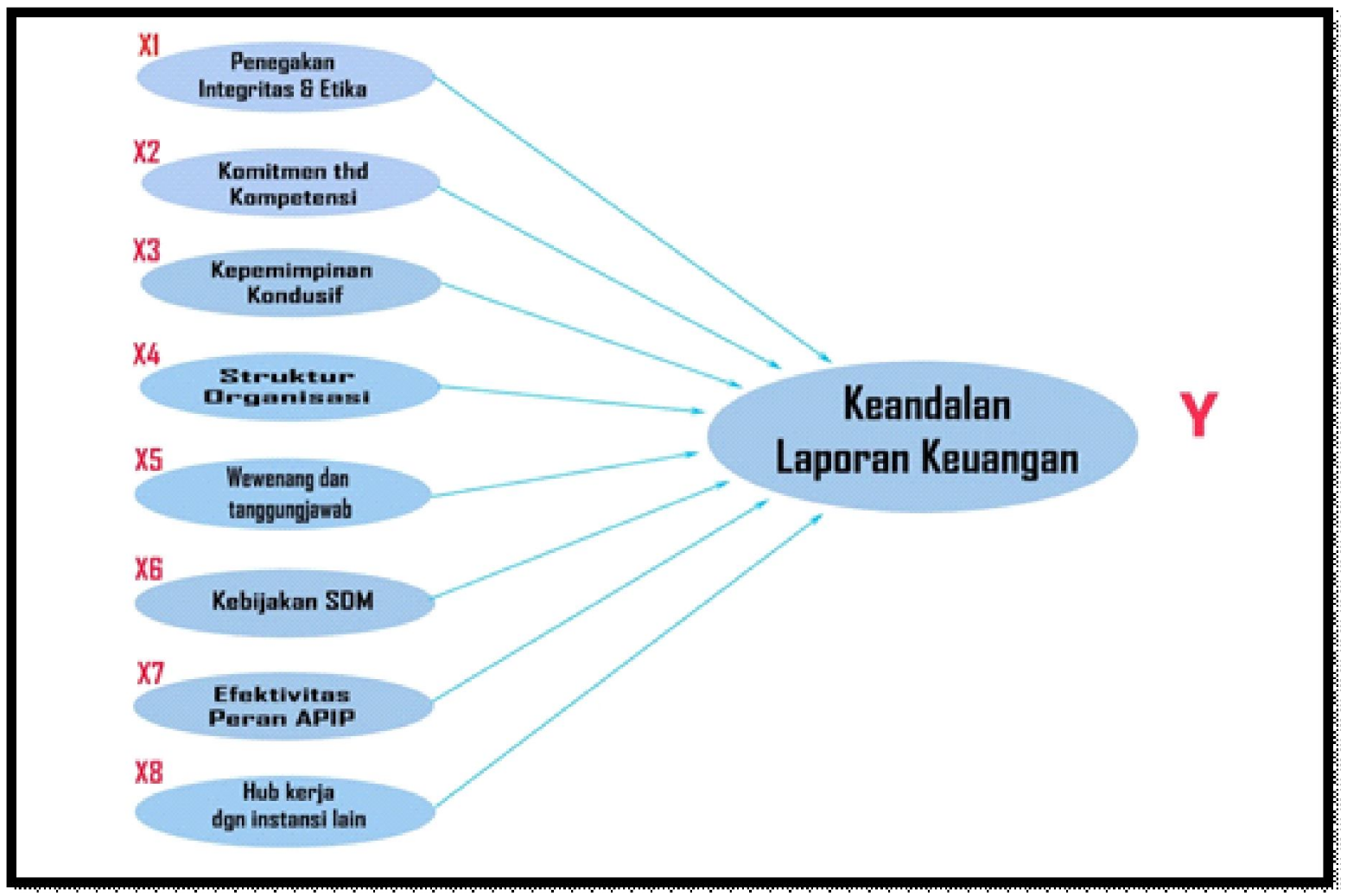


pengolahan datanya dilakukan dengan metode purposive sampling.

Teknik Analisis Data. Teknik analisis data yang digunakan dalam penelitian ini adalah Partial Least Square (PLS). PLS adalah metode alternatif dalam persamaan struktural. PLS merupakan salah satu metode untuk melaksanakan model Structural Equation Modelling (SEM). Model PLS digunakan pada saat dasar teori perancangan model lemah dan indikator pengukuran tidak memenuhi model pengukuran yang ideal. PLS dapat digunakan dengan jumlah sampel yang tidak besar dan dapat diterapkan pada semua skala data (Ghozali 2011).

Model Spesifikasi. Model dalam penelitian ini adalah struktural. Indikator pada penelitian ini bersifat reflektif. Model analisis jalur secara persamaan pada Gambar 2.

\section{HASIL DAN PEMBAHASAN}

Menilai Measurement Model atau Outer Model. Model pengukuran atau outer model diukur dengan tiga kriteria yaitu Convergent Validity, Discriminant Validity dan Composite Reliability. Convergent validity dari model pengukuran dengan refleksif indikator dinilai berdasarkan korelasi antara item score/component score yang diestimasi dengan Soflware PLS.

Ukuran refleksif individual dikatakan tinggi jika berkorelasi lebih dari 0,70 dengan konstruk yang diukur. Namun menurut Chin, 1998 (dalam Ghozali, 2006) untuk penelitian tahap awal dari pengembangan skala pengukuran nilai loading 0,5 sampai 0,6 dianggap cukup memadai. Pada penelitian ini semua convergent validity masingmasing variabel bernilai di atas 0,5 yang artinya measurement model masing-masing variabel pada penelitian ini baik.

Uji Validitas Konstruk. Ghozali (2008) menjelaskan bahwa discriminant validity dari model pengukuran dengan refleksif indikator dinilai dengan membandingkan akar kuadrat dari average variance extracted $(\sqrt{A V E})$ untuk setiap konstruk dengan konstruk lainnya dalam model. Model

Gambar 2

Model Persamaan

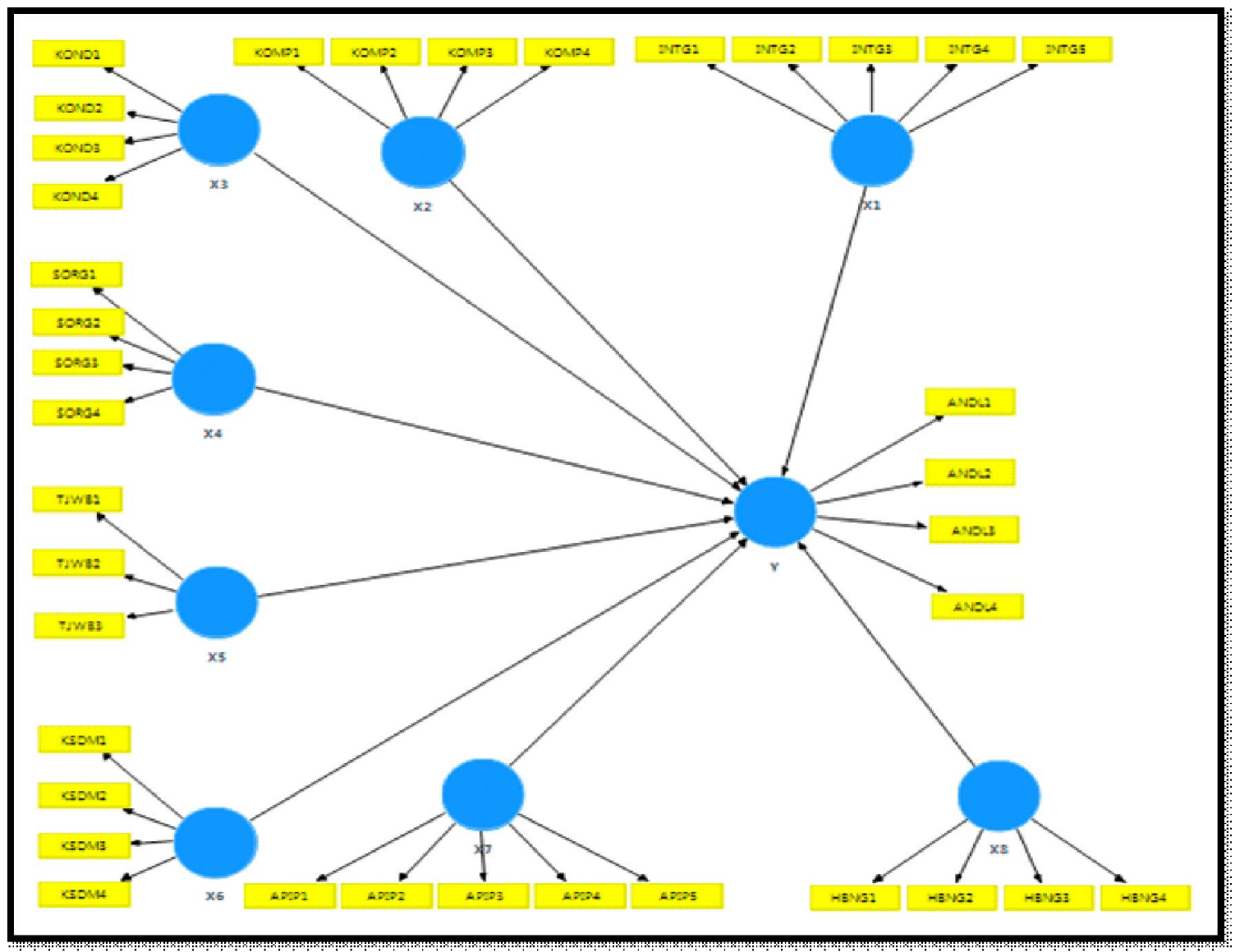


mempunyai discriminant validity yang cukup jika akar AVE untuk setiap konstruk lebih besar daripada korelasi antara konstruk dengan konstruk lainnya. Pada tabel 1 dapat dilihat bahwa akar AVE tiap konstruk lebih besar daripada akar AVE korelasi antara konstruk dengan konstruk lainnya.

Uji Reliabilitas Konstruk. Disamping melalui uji validitas, tiap konstruk juga harus memenuhi syarat reliabilitas, uji reliabilitas suatu konstruk diukur dengan dua kriteria yaitu Composite
Reliability dan cronbach alpha dari blok indikator yang mengukur konstruk. Suatu konstruk dinyatakan reliabel jika nilai composite reliability maupun cronbach alpha di atas 0,70 (Ghozali, 2015). Tabel 2 menunjukkan seluruh nilai cronbach alpha bernilai di atas 0.70

Pengujian Hipotesis. Hasil pengujian hipotesis menggunakan PLS dapat dilihat dari nilai Path coefficient dan t-statistics yang terangkum dalam tabel 3 .

Tabel 1

Discriminat Validity

\begin{tabular}{|c|c|c|c|c|c|c|c|c|c|}
\hline & $\begin{array}{l}\text { Efektivitas } \\
\text { Peran APIP }\end{array}$ & $\begin{array}{c}\text { Hubungan dg } \\
\text { Instansi Lain }\end{array}$ & $\begin{array}{l}\text { Integritas } \\
\text { dan Etika }\end{array}$ & $\begin{array}{c}\text { Keandalan } \\
\text { LK }\end{array}$ & $\begin{array}{c}\text { Kebijakan } \\
\text { SDM }\end{array}$ & $\begin{array}{c}\text { Kepemimpinan } \\
\text { Kondusif }\end{array}$ & $\begin{array}{c}\text { Komitmen } \\
\text { thd } \\
\text { Kompetensi }\end{array}$ & $\begin{array}{c}\text { Struktur } \\
\text { Organisasi }\end{array}$ & \begin{tabular}{|c|} 
Wewenang \\
$\& \mathrm{Tg}$ \\
Jawab
\end{tabular} \\
\hline Efektivitas Peran APIP & 0.792 & & & & & & & & \\
\hline Hubungan dg Instansi Lain & 0.675 & 0.817 & & & & & & & \\
\hline Integritas dan Etika & 0.542 & 0.625 & 0.782 & & & & & & \\
\hline Keandalan LK & 0.608 & 0.639 & 0.552 & 0.854 & & & & & \\
\hline Kebijakan SDM & 0.639 & 0.548 & 0.517 & 0.476 & 0.817 & & & & \\
\hline Kepemimpinan yg Kondusif & 0.638 & 0.585 & 0.661 & 0.571 & 0.776 & 0.809 & & & \\
\hline Komitmen thd Kompetensi & 0.559 & 0.440 & 0.575 & 0.476 & 0.484 & 0.592 & 0.745 & & \\
\hline Struktur Organisasi & 0.673 & 0.569 & 0.431 & 0.355 & 0.655 & 0.566 & 0.431 & 0.844 & \\
\hline Wewenang \& Tg Jawab & 0.603 & 0.680 & 0.679 & 0.578 & 0.679 & 0.645 & 0.597 & 0.634 & 0.863 \\
\hline
\end{tabular}

Tabel 2

Cronbach Alpha

\begin{tabular}{|l|r|}
\hline & Cronbachs Alpha \\
\hline Efektivitas Peran APIP & 0.855 \\
\hline Hubungan dg Instansi Lain & 0.833 \\
\hline Integritas dan Etika & 0.840 \\
\hline Keandalan LK & 0.876 \\
\hline Kebijakan SDM & 0.848 \\
\hline Kepemimpinan yg Kondusif & 0.827 \\
\hline Komitmen thd Kompetensi & 0.769 \\
\hline Struktur Organisasi & 0.866 \\
\hline Wewenang \& Tg Jawab & 0.831 \\
\hline
\end{tabular}

Tabel 3

PATH COEFFICIENTS DAN T-STATISTIK

\begin{tabular}{|c|c|c|c|c|c|}
\hline & Original Sample (0) & Sample Mean (M) & Standard Error (STERR) & T Statistics (|O/STERR) & PValues \\
\hline Efektivitas Peran APIP > Keandalan LK & 0.331 & 0.394 & 0.204 & 1.623 & 0.063 \\
\hline Hubungan dg Instansi Lain > Keandalan LK & 0.310 & 0.264 & 0.227 & 1.366 & 0.086 \\
\hline Integritas dan Etika $>$ Keandalan LK & 0.032 & 0.071 & 0.181 & 0.175 & 0.430 \\
\hline Kebijakan SDM > Keandalan LK & -0.049 & -0.051 & 0.192 & 0.256 & 0.399 \\
\hline Kepemimpinan yg Kondusif $>$ Keandalan LK & 0.199 & 0.186 & 0.236 & 0.845 & 0.199 \\
\hline Komitmen thd Kompetensi $\rightarrow>$ Keandalan LK & 0.041 & 0.056 & 0.166 & 0.246 & 0.403 \\
\hline Struktur Organisasi $>$ Keandalan LK & -0.289 & 0.279 & 0.167 & 1.727 & 0.042 \\
\hline Wewenang \& Tg Jawab > Keandalan LK & 0.210 & 0.176 & 0.184 & 1.142 & 0.127 \\
\hline
\end{tabular}




\section{Hasil Pengujian Hipotesis 1: Pengaruh} penegakan integritas dan etika terhadap keandalan laporan keuangan Kementerian/ Lembaga

Variabel penegakan integritas dan etika tidak berpengaruh positif dengan nilai Original Sample sebesar 0,032 dengan nilai T-Statistik sebesar 0, $175(<1,296)$ dan P Values sebesar $0,430(\mathrm{p}>0,1)$ yang berarti tidak signifikan pada alpha $10 \%$. Dengan demikian hipotesa pertama (H1) ditolak. Sehingga dapat disimpulkan bahwa Penegakan Integritas dan Etika tidak memberikan dampak yang berarti terhadap keandalan Laporan keuangan.

2. Hasil pengujian hipotesis 2 : Pengaruh komitmen terhadap kompetensi terhadap keandalan laporan keuangan

Variabel komitmen terhadap kompetensi tidak berpengaruh positif terhadap keandalan laporan keuangan kementerian/lembaga, hal ini dapat dilihat dari nilai original sampel sebesar 0,041 dengan nilai T-statistik sebesar $0,476(<1,296)$ dan $\mathrm{P}$ values sebesar $0,403(>0,1)$ yang berarti tidak signifikan pada alpha $10 \%$. Dengan demikian hipotesa kedua $(\mathrm{H} 2)$ ditolak. Sehingga dapat disimpulkan bahwa Komitmen terhadap kompetensi tidak memberikan dampak yang berarti terhadap keandalan Laporan keuangan kementerian/lembaga.

3. Hasil pengujian hipotesis 3 : Pengaruh kepemimpinan yang kondusif terhadap keandalan laporan keuangan kementerian/ lembaga.

Variabel kepemimpinan yang kondusif tidak berpengaruh positif terhadap keandalan laporan keuangan kementerian/lembaga, hal ini dapat dilihat dari nilai original sampel sebesar 0,199 dengan nilai T-statistik sebesar $0,845(<1,296)$ dan $\mathrm{P}$ values sebesar $0,199(\mathrm{p}>0,10)$ yang berarti tidak signifikan pada alpha $10 \%$. Dengan demikian hipotesa ketiga (H3) ditolak. Sehingga dapat disimpulkan bahwa kepemimpinan yang kondusif tidak memberikan dampak yang berarti terhadap keandalan Laporan keuangan kementerian/lembaga.

4. Hasil pengujian hipotesis 4 : Pengaruh Struktur organisasi yang sesuai kebutuhan terhadap keandalan laporan keuangan

\section{kementerian/lembaga.}

Variabel struktur organisasi tidak berpengaruh positif terhadap keandalan laporan keuangan kementerian/lembaga, hal ini dapat dilihat dari nilai original sampel sebesar $-0,289$ dengan nilai T-statistik sebesar 1,727 (>1,296) dan P values sebesar $0,042(\mathrm{p}<0,10)$ yang berarti signifikan pada alpha $10 \%$. Dengan demikian hipotesa keempat (H4) ditolak. Sehingga dapat disimpulkan bahwa struktur organisasi tidak memberikan dampak yang berarti terhadap keandalan Laporan keuangan kementerian/ lembaga.

5. Hasil pengujian hipotesis 5 : Pengaruh pendelegasian wewenang dan tanggung jawab terhadap keandalan laporan keuangan kementerian/lembaga.

Variabel pendelegasian wewenang dan tanggung jawab tidak berpengaruh positif terhadap keandalan laporan keuangan kementerian/ lembaga, hal ini dapat dilihat dari nilai original sampel sebesar 0,210 dengan nilai T-statistik sebesar $1,142(<1,296)$ dan $\mathrm{P}$ values sebesar $0,127(\mathrm{p}>0,10)$ yang berarti tidak signifikan pada alpha $10 \%$. Dengan demikian hipotesa kelima (H5) ditolak. Sehingga dapat disimpulkan bahwa pendelegasian wewenang dan tanggung jawab tidak memberikan dampak yang berarti terhadap keandalan Laporan keuangan kementerian/lembaga.

6. Hasil pengujian hipotesis 6 : Pengaruh kebijakan sumber daya manusia terhadap keandalan laporan keuangan kementerian/ lembaga.

Variabel kebijakan sumber daya manusia tidak berpengaruh positif terhadap keandalan laporan keuangan kementerian/lembaga, hal ini dapat dilihat dari nilai original sampel sebesar $-0,049$ dengan nilai T-statistik sebesar $0,256(<1,296)$ dan $P$ values sebesar $0,399(p>0,10)$ yang berarti tidak signifikan pada alpha $10 \%$. Dengan demikian hipotesa keenam (H6) ditolak. Sehingga dapat disimpulkan bahwa kebijakan sumber daya manusia tidak memberikan dampak yang berarti terhadap keandalan Laporan keuangan kementerian/lembaga.

7. Hasil pengujian hipotesis 7 : Pengaruh efektivitas peran Aparat Pengawas Intern 
Pemerintah (APIP) terhadap keandalan laporan keuangan kementerian/lembaga.

Variabel efektivitas peran APIP berpengaruh positif terhadap keandalan laporan keuangan kementerian/lembaga, hal ini dapat dilihat dari nilai original sampel sebesar 0,331 dengan nilai T-statistik sebesar 1,623 (>1,296) dan P values sebesar $0,053(p<0,10)$ yang berarti signifikan pada alpha $10 \%$. Dengan demikian hipotesa ketujuh (H7) diterima. Sehingga dapat disimpulkan bahwa efektivitas peran APIP memberikan dampak yang berarti terhadap keandalan Laporan keuangan kementerian/ lembaga.

8. Hasil pengujian hipotesis 8 : Pengaruh Hubungan dengan instansi lain terhadap keandalan laporan keuangan kementerian/ lembaga.

Variabel hubungan dengan instansi lain berpengaruh positif terhadap keandalan laporan keuangan kementerian/lembaga, hal ini dapat dilihat dari nilai original sampel sebesar 0,310 dengan nilai T-statistik sebesar 1,366 (>1,296) dan $P$ values sebesar $0,086(\mathrm{p}<0,1)$ yang berarti signifikan pada alpha $10 \%$. Dengan demikian hipotesa kedelapan (H8) diterima. Sehingga dapat disimpulkan bahwa hubungan dengan instansi lain memberikan dampak yang berarti terhadap keandalan Laporan keuangan kementerian/lembaga.

\section{KESIMPULAN}

Berdasarkan hasil penelitian dan pembahasan yang telah dilakukan menunjukkan bahwa variabel penegakan integritas dan etika, komitmen terhadap kompetensi, kepemimpinan yang kondusif, struktur organisasi, pendelegasian wewenang dan tanggung jawab, kebijakan sumber daya manusia (SDM) tidak berpengaruh terhadap keandalan laporan keuangan kementerian/lembaga. Sedangkan variabel efektivitas peran Aparat Pengawas Intern Pemerintah (APIP) dan Hubungan dengan instansi lain berpengaruh positif terhadap keandalan laporan keuangan kementerian/lembaga.

Berarti hal ini dapat disimpulkan secara keseluruhan lingkungan pengendalian dalam Sistem Pengendalian Internal Pemerintah belum berjalan efektif, hal ini dibuktikan dari jawaban responden yang mencerminkan bahwa kementerian/lembaga belum sepenuhnya menciptakan kondisi lingkungan pengendalian yang ideal, dari penelitian ini juga terlihat bahwa sebanyak $28 \%$ dari Kementerian/ lembaga yang disurvei, tidak pernah menyelenggarakan diklat/bimtek mengenai SPIP, dan sebanyak $47 \%$ masih minim mengadakan diklat mengenai SPIP.

Kurang terciptanya kondisi lingkungan pengendalian juga dapat membuat sistem pengendalian internal tidak berjalan efektif, hal ini disebabkan bahwa lingkungan pengendalian sebagai pondasi awal sistem pengendalian intern, belum dapat memberikan dukungan atas unsur-unsur lainnya dalam SPIP yaitu penilaian resiko, kegiatan pengendalian, informasi dan komunikasi dan monitoring pengendalian intern.

Namun demikian keandalan laporan keuangan yang tercipta lebih banyak dipengaruhi oleh efektivitas peran Aparat pengawas intern pemerintah (APIP) melalui kegiatan reviewnya terhadap laporan keuangan sebelum diserahkan ke Badan Pemeriksa Keuangan untuk diaudit. Selain itu hubungan kerja dengan instansi lain, dalam hal ini Kementerian keuangan juga sangat mempengaruhi keandalan laporan keuangan kementerian/lembaga.

Saran. Berdasarkan hasil penelitian dan keterbatasan penelitian yang telah diuraikan di atas, maka terdapat beberapa saran untuk penelitian selanjutnya sebagai berikut :

1. Bagi pihak-pihak yang terkait laporan keuangan kementerian/lembaga untuk terus menciptakan kondisi lingkungan pengendalian yang efektif, karena dengan memperhatikan dan meningkatkan efektivitas lingkungan pengendalian akan dapat menciptakan sistem pengendalian intern yang efektif, yang akhirnya akan menghasilkan laporan keuangan yang andal.

2. Untuk penelitian selanjutnya perlu adanya penambahan variabel-variabel lain seperti tekanan waktu penyusunan laporan keuangan, reward atau insentif dan lain-lain 


\section{DAFTAR PUSTAKA}

Altamuro, J. d. (2010). How Does Internal Control regulation affect financial reporting. Journal of Accounting and Economics 49.

Arens, Elder, dan Beasley. Auditing and Assurance Services An Integrated Approach. 2012. New Jersey

Badan Pemeriksa Keuangan. (2014, Juni 23). ttp:// www.bpk.go.id. Diambil kembali dari ttp:// www.bpk.go.id/news/bpk-menyerahkanlaporan-hasil-pemeriksaan-atas-laporankeuangan-tahun-2013-kepada-37kementerianlembaga

Badan Pemeriksa Keuangan Republik Indonesia. (2007). Standar Pemeriksaan Keuangan Negara. Jakarta.

Badan Pengawas Keuangan dan Pembangunan. (2009, Desember 7). Pedoman Teknis Penyelenggaraan SPIP Sub unsur Pembentukan Struktur Organisasi yang sesuai dengan kebutuhan. DKI Jakarta, Indonesia: BPKP.

Badan Pengawas Keuangan dan Pembangunan. (2009, Desember 7). Pedoman Teknis Penyelenggaraan SPIP Sub Unsur Peran APIP yang Efektif. Jakarta.

Baiman, S. (1990). Agency research in managerial accounting: a second look Accounting, Organizations and Society 15 (4): 341-371.

Badan Pengawas Keuangan dan Pembangunan. (2009, 7 Desember). Pedoman Teknis SPIP Sub Unsur Hubungan dengan Instansi lain. Jakarta.

Chariri,Anis dan Ghozal,Imam. (2005). Teori Akuntansi. Semarang: Badan Penerbit Universitas Diponegoro.

D'Aquila, J. M. (1998). Is the control environment related to financial. Managerial Auditing Journal.

Elder, J. Randal et al. (2010). Auditing and Assurance Services: An Integrated Approach. New Jersey: Pearson Education, Inc.

Ghozali, I. (2011). Aplikasi Analisis Multivariate dengan Program IBM SPSS 19. Semarang: Badan Penerbit Universitas Diponegoro.

Ghozali, Imam dan Fuad. (2008). Structural Equation Modeling, Teori, Konsep, dan Aplikasi. Semarang: Badan Penerbit Universitas Diponegoro.

Ghozali,Imam dan Hengky Latan. (2015). Partial Least Squares, Smart PLS 3.0. Semarang: Badan Penerbit - UNDIP.
Gudono. (2011). Analisis Data Multivariat. Yogyakarta: BPFE.

Jensen, M. C dan William H. Meckling. (1976). Theory of the Firm: Managerial Behavior, Agency Costs and Ownership Structure. Journal of Financial Economics.

Karwedar, W. (2009). Opini Audit dan Sistem Pengendalian Intern. Universitas Diponegoro.

Kawedar,Warsito et all. (2008). Akuntansi Sektor Publik. Semarang: Badan Penerbit Undip.

Kementerian Keuangan. (2010). Modul Pelaporan Keuangan dan Kinerja Instansi Pemerintah. Jakarta.

Mardiasmo. (2004). Akuntansi Sektor Publik. Yogyakarta: ANDI Yogyakarta.

Menpan RB. (2014, Juni 20). APIP Lemah, masih ada K/L yang Disclaimer. Diambil kembali dari http://menpan.go.id/berita-terkini/2489-diyogya-kritik-terbanyak-dapat-walikota-awar

Messier et all. (2006). Auditing dan Assurance Services "A Systematic Approach". Jakarta: Salemba Empat.

Messier, W. (2005). Auditing and Assurance Services. Jakarta: Salemba Empat.

Mulyadi. (2002). Auditing. Jakarta: Salemba Empat.

Pemerintah Republik Indonesia. (2014, Juni). Laporan Keuangan Pemerintah Pusat Tahun 2013.

Peraturan Menteri Keuangan Nomor 41/PMK.09/ 2010. (2010). Standar reviu atas Laporan Keuangan Kementerian/Lembaga.

Peraturan Pemerintah No. 60 Tahun 2008 Tentang Sistem Pengendalian Intern Pemerintah. (t.thn.).

Peraturan Pemerintah No. 71 Tahun 2010. Standar Akuntansi Pemerintah.

Peraturan Pemerintah No. 8 Tahun 2006 Tentang Pelaporan Keuangan dan Kinerja Instansi Pemerintah.

Pusdiklatwas BPKP. (2009). Modul Lingkungan Pengendalian. Jakarta.

Sabastian. (2012). Pengaruh Soft Control Lingkungan Pengendalian dalam Sistem Pengendalian Intern Pemerintah Terhadap Pencegahan Fraud. Tesis Undip.

Siregar, L. (2012). Pengaruh Komponen Lingkungan Pengendalian (Control Environment) terhadap kinerja unit internal kontrol pada kantor cabang PT. Bank ABC. Tesis Undip.

Soemarso, S. (1990). Akuntansi : Suatu Pengantar. Jakarta: Rineka Cipta.

Sucipto, A. (2012). Analisis Pengaruh Keandalan 
Sistem Pengendalian Intern Melalui Capaian Kinerja, Keandalan Laporan Keuangan, Serta Kepatuhan atas ketentuan bantuan operasional sekolah dalam mendeteksi kemungkinan terjadinya kerugian keuangan negara. Tesis Undip.

Sukmaningrum, T. (2012). Analisis Faktor-faktor yang mempengaruhi kualitas informasi laporan keuangan pemerintah daerah. Tesis, Undip.

Umar, H. (2003). Metode Riset Bisnis. Jakarta: Gramedia Pustaka Utama.

Undang-undang No. 17 Tahun 2003 Tentang Keuangan Negara.

Undang-undang No. 1 Tahun 2004 Tentang Perbendaharaan Negara.

Undang-undang No. 15 Tahun 2004 Tentang
Pemeriksaan dan Pengelolaan Keuangan Negara.

Wamenkeu. (2015, Februari 24). APIP Pegang Peran Penting Wujudkan Opini WTP LKPP.Diambil kembali dari http:// www.kemenkeu.go.id/Berita/wamenkeu-apippegang-peran-penting-wujudkan-opini-wtp-lkpp Whittington, R dan Kurt Pany. (2008). Principles of Auditing and Other Assurance Services. New York: McGraw Hill.

Winidyaningrum, C. (2009). Pengaruh Sumber Daya Manusia dan Pemanfaatan Teknologi Informasi terhadap Keterandalan dan ketepatwaktuan pelaporan keuangan pemerintah daerah dengan variabel intervening pengendalian intern akuntansi. Tesis, UNS 